\title{
INTERNATIONAL ORGANIZATIONS AS SUBJECTS OF INTERNATIONAL LAW RULES INTERPRETATION
}

\section{Svitlana Karvatska}

Doctor in Law, Associate Professor at the Department of European Law and Comparative Law Studies, Yuriy Fedkovych Chernivtsi National University, Ukraine e-mail: svitlana.karvatska288822@gmail.com,orcid.org/0000-0001-9948-4866

\section{Tetyana Gnatuyk}

Ph.D, Senior Lecturer at the Department of European Law and Comparative Law Studies, Yuriy Fedkovych Chernivtsi National University, Ukraine e-mail: t.gnatuyk@chnu.edu.ua,orcid.org/0000-0001-7409-6373

\section{Summary}

This paper aims to analyze an interpretive activity of international organizations as a means to solve the problem of paramount importance for ensuring updating of international law rules and the whole mechanism of international law action in the process of rules implementation. The methodology is based on a comprehensive approach to the analysis of the object and subject of research, which covers philosophical and legal methods - dialectical method of scientific knowledge, system-structural method, empirical method, hermeneutic method, synergetic and formal-legal methods of scientific research.

As a result, the growing role of international organizations as subjects of interpretation, which do not only play an essential role in international law-making and the implementation of international law but also take an active part in their interpretation, was proved. In interpreting their charters, international bodies and organizations certainly influence the content of other international norms. At the current stage, it is necessary to define international organizations' interpretive activity as a particular type of international law-making, which consists in the official interpretation of international legal rules contained in the relevant acts. Nevertheless, they do not acquire the status of law-making bodies, and their decisions and conclusions are of a recommendatory nature.

Keywords: interpretation of international law, United Nations General Assembly, United Nations Security Council, law-making, soft law.

DOI https://doi.org/10.23856/4324

\section{Introduction}

At the current stage, international organizations' interpretive activity is a distinct type of international law-making, which consists in the official interpretation of international legal rules contained in the relevant acts. In carrying out the interpretive function, international bodies and organizations also influence the content of other international rules, a practical example of which is the United Nations activities. Interpretation of the UN Charter's goals and principles directly affects international law as a whole, which goals and principles of which they also are. Thus, any interpretation is carried out in the light of goals and principles of the Charter of United Nations as a universal international intergovernmental organization of general competence. 
This article aims to study the process of international law interpretation by international organizations, to determine the role of international bodies and organizations as subjects of interpretation, in particular, to characterize the activities of the UN General Assembly and the UN Security Council in international law interpretation.

The methodology is based on a comprehensive approach to analyzing the object and subject of research, which covers philosophical and legal methods. The methodological basis is the dialectical method of scientific cognition, which provided the study of the connection between doctrine and practice. Particularly vital among interdisciplinary methods is the system-structural method, on the basis of which the systemic relations in the international organizations system were studied and substantiated. The author's conclusions are grounded on scientific analysis results, carried out using the empirical method of the research of international organizations' law enforcement practice. As a critical methodological principle, the hermeneutic method was used, which allowed studying international organizations' legal interpretation. The synergetic method, being a qualitatively new approach in scientific cognition, allowed to determine basic principles and patterns of functioning of international organizations as interpretation subjects and the formation of organizations interpretive methodology. The article also used the formal-legal method for treaty analysis.

The concept, international organizations' legal nature, organizational structure and functions of international organizations, forms of law-making are the subject of Ukrainian scholars`active research (M. Baimuratov, S. Bilotsky, M. Buromensky, V. Butkevych, O. Butkevych, V. Vasylenko, Yu. Voloshin, M. Hnatovsky, T. Danilchenko, V. Denisov, O. Kyivets, I. Lukashuk, V. Mytsyk, L. Tymchenko, O. Tragnyuk, O. Shpakovych, etc.). In the foreign doctrine of international law, certain aspects of this issue have been studied in one way or another by such scholars as G. Ab-Saab, D. Ancilotti, A. Aust, O. Elias, M. Fitzmaurice, M. Lennard, U. Linderfalk, P. Merkouris, J. Pauwelyn, G. Schwazenberg, P. Van den Bossche, I. Van Damme, G. White.

However, the problem of international organizations` interpretive activity remains debatable, especially in the context of distinguishing between legal interpretation's content and law-making of international organizations` activities. Based on the above, T. Danilchenko (2017) proposes to consider international organizations' law-making in two dialectically combined dimensions - imperative ("hard") and recommendatory (political-legal or "soft"). The latter, as noted by K. Smirnova (2012), is a field for discussion in international law theory. The "soft" law concept is a kind of tension point for different ideas and views, being sometimes contradictory, even though "soft" law received a particular vision in European Union law (Smirnova, 2012, (3): 74). The study of prof. Shpakovich O. M. (Shpakovich, 2016: 175) has convincingly developed this idea. According to the author, "soft" law rules are contained in international organizations ' resolutions of being not mandatory and not formally binding member states. However, as the researcher emphasizes, these rules are respected by the states and are implemented in the national law by similar meaning norms similar. The author gives a reasoned explanation, noting that "soft" law rules, having great political and moral importance, are usually created by organizations with considerable authority.

Illustrating the role that international intergovernmental organizations can play in the law-making process, D. Skrynka (Skrynka, 2019 (1): 255) cites, as an example, the General Agreement on Tariffs and Trade (GATT), and since 1995 - the World Trade Organization (WTO). The author claims that within multilateral negotiations framework of the Uruguay Round (1986-1993), almost two dozen texts of treaties, determining both the foreign and domestic policies of most modern states, were prepared. 


\section{Interpretive and law-making functions of international organizations: main discussions}

One should note that scholars' positions on international organizations' law-making functions can be grouped into two categories: 1) denial of international organizations' ability to make binding decisions not directly provided by the charter; 2) recognition of the binding nature of international organizations' decisions, issued for the execution of its functions. Most international law professionals are interested in such a phenomenon as the decision of an international organizations ' decisions as "soft" law. O. Shpakovych (Shpakovych, 2013: 34-47, 34-47) believes that, based on modern international organizations practice, one should pay attention to the resolutions of many regional organizations, especially to European human rights protection mechanisms, which, being by their legal nature the norms of "soft law," are "hard" by its international legal consequences.

It is necessary to distinguish between interpretation possibilities of interpretation: 1) universal organizations (e.g., UN) and 2) organizations with a limited number of participants, such as regional organizations. Universal organizations represent the international community as a whole and can, through interpretation, make significant changes to general international law, including its mandatory rules. According to the Vienna Convention on the Law of Treaties, such rules are created and changed by the international community as a whole (Karvatska, 2019 (1): 187-190). Interpretation, carried out by organizations with a limited number of participants, may not lead to the repeal or modification of general international law.

Several Council of Europe agreements provide for the possibility of settling their application or interpretation in Council of Europe bodies. In particular, the European Committee on Legal Cooperation of the Council of Europe may, by agreement of States, settle disputes concerning the interpretation or application of the Civil and Criminal Law Conventions on Corruption, 1999 (Article 21), The European Committee on Crime Problems of the Council of Europe is empowered to consider, by agreement of States, disputes concerning the interpretation or application of the Convention on Laundering, Search, Seizure and Confiscation of the Proceeds from Crime, 1990 (Article 42), and to promote the amicable settlement of any difficulties, which may arise in connection with the application of the Convention on the Transfer of Sentenced Persons, 1983 (Article 23), the European Convention on the International Validity of Criminal Sentences of 1970 (Article 65), the European Convention on the Suppression of Terrorism of 1977 (Article 9), the European Convention on the Transfer of Proceedings in Criminal Matters of 1972 (Article 44).

Decisions, resolutions, and other international organizations ' practices can in themselves be attributed to treaty interpretation. This principle, for example, is stated in Art. 2 (j) of the Vienna Convention of 1986, which mentions "established practice of organization" as a form of "rules of the organization". International organizations" practice in applying their constituent documents relates to paragraph 3 of the Draft Conclusion 12 of the International Law Commission. Reports from international organizations prepared on the basis of a mandate to gather information on States' practices in specific areas can be critical in assessing such practices.

Paragraph 4 of the draft conclusions of the International Law Commission, adopted at the Seventieth Session of the UN General Assembly, stipulates that the "case-related rules of interpretation" contained in the constituent act of an international organization may prevail over general interpretation rules according to the VCLT (Dörr, Schmalenbach, 2018: 576-577). If, for example, the constituent act contains a reservation, such as a paragraph 2 of Art. IX of the 
Agreement Establishing the World Trade Organization (commonly known as the "Marrakesh Agreement"), according to which a particular procedure carries out the interpretation of the act, it should be assumed that parties, having reached an agreement after the treaty conclusion, do not want to circumvent this procedure according to paragraph 3 (a) of Art. 31. Such a particular process under the treaty and the subsequent agreement under paragraph 3 (a) of Art. 31 may, however, be compatible if they "perform different functions and have different legal consequences" (World Trade Organization, 2012. United States - Measures Affecting the Production and Sale of Clove Cigarettes, Paras 252-257). Only in rare cases do constituent acts contain positive procedural or substantive rules concerning their interpretation (Dörr, Schmalenbach, 2018: 577). In its commentary to Art. 2 (j) of the 1986 Vienna Convention, International Law Commission noted that the significance of a particular organization's practice might depend on specific rules and characteristics of an organization expressed in its founding act: "Indeed, most international organizations in a few years establish a practice, which becomes an inalienable part of their rules." However, mention of practice does not mean that it has the same status in all organizations; on the contrary, each organization has certain peculiarities in this matter".

International organizations` decisions arising from multilateral contractual law (i.e., constituent documents) or its application may affect the interpretation of a multilateral contractual rule (or customary law), an unappealable nature of which is recognized and accepted per Art. 53. However, the question of whether the decision itself is mandatory in terms of recognizing the invalidity of conflicting contractual obligations of the Member States is not resolved (Wolfke, 1974 (6): 154). One should determine this possible effect solely based on the constituent act.

In the context of the documents' interpretation effectiveness of international organizations, the question of their correlation with the mandatory norms of jus cogens is essential. International organizations ' decisions, contradicting jus cogens, are invalid for two reasons. Firstly, international organizations decisions follow from the constituent act of the organization, i.e., the agreement on the establishment of the organization. In order to prevent the invalidity of the latter under Art. 53, the constitutive act should be interpreted as not allowing decision-making or action-taking contrary to jus cogens by international bodies. Secondly, as international legal entities, international organizations have rights and obligations arising not only from their constituent acts but also from general international law rules, including inalienable jus cogens. In this respect, international organizations' legal position is very similar to the states ' stance: jus cogens' force of validity affects international organizations' contractual relations (Article 53) and their unilateral legal acts. Even the UN Security Council, acting in accordance with Chapter VII, has no particular political or legal position in the area of jus cogens obligations (Reinisch, 2001 (95), 4: 859).

European Court (now the General Court of European Union), in its well-known judgment "Kadi and Barakaat $v$ Council and Commission," repealing the appeal, ruled: "The Court is empowered to review, indirectly, the legality of resolutions referred to in the Security Council in relation to jus cogens, what is understood as a set of public international law higher rules binding for all subjects of international law, including United Nations bodies, and from which derogation is impossible.

In this regard, acts of international organizations ' bodies created to promote the development of a particular international law area are of special interest. For example, the United Nations Commission on International Trade Law (UNCITRAL) was established as a subsidiary body of the United Nations General Assembly to promote the progressive harmonization and unification of international trade law. The Commission develops conventions, model laws, rules, legal and legislative guidelines, and recommendations and carries out other activities to 
realize its goals. The Commission is a specialized body in the field of international trade law and international commercial turnover. It is obvious that practice generalization, conducted by UNCITRAL, in this area is a particular legal analysis, based on which conclusions are drawn about the understanding and implementation of specific rules. These conclusions can be qualified as a competent international legal interpretation of international law rules, by which national courts should be guided (despite the recommendatory nature of UNCITRAL acts). Such a normativity stems precisely from the competence in a particular area of this body, from the fact that conclusions about interpretation are made based on the established state practice and aim to ensure the uniform application of treaty rules.

\section{Activities of the UN General Assembly in the process of international law interpretation: features and innovations}

UN activities are especially relevant in the context of international law interpretation's problem. On the other hand, any interpretation is carried out in the light of UN Charter goals and principles. The most convincing confirmation of this statement is the Declaration on Principles of International Law concerning Friendly Relations and Cooperation among States in accordance with the Charter of the United Nations, adopted by the UN General Assembly in 1970. A detailed analysis of the document, including the expressiveness of its title, proves that this Declaration does not only enumerate principles, explaining their content but to a large extent carries out their in-depth interpretation.

The problem of international organizations ' constituent acts interpretation, first of all, of the UN Charter, has acquired important practical significance today. Acts of this kind Charters by their legal nature - are treaties. However, they have significant specifics, which is reflected in Vienna Conventions. The International Court of Justice also assumes that treaty interpretation's general principles and rules can be applied to the UN Charter, as the Charter is a multilateral treaty, which, however, has certain specifics. Bodies and organizations should interpret the Charter in the part that relates to their competence and regulates their activities. During the UN Charter development, it was determined that "each body will interpret Charter parts relating to its specific functions." Such an interpretation becomes mandatory if the states recognize it. This is how constituent acts ' content of international organizations develops. As Declaration's name suggests, Declaration covers principles of the Charter, the presentation of their content, in other words, mainly about their interpretation. Moreover, the Declaration has become an act of progressive development of fundamental principles ' content. Declaration's provisions were in themselves of a recommendatory nature. However, the further recognition by states of their content's legal force gave it the status of universal customary law rules. Analyzing the Resolutions of the UN General Assembly, T.S. Danilchenko notes that they, firstly, most often cover issues that are not addressed by contractual regulations; secondly, they are more operational than agreements, which is essential for the interpretation effectiveness (Danilchenko, 2016: 161-163).

One should note that international organizations have the right to interpret the Charter, but such interpretation is binding only for the organization itself and its bodies. Such interpretive activities also significantly affect the rights and responsibilities of UN member states. An example of a critical resolution for Ukraine is the Resolution of the UN General Assembly (hereinafter - the UN General Assembly) on the territorial integrity of Ukraine № 68/262. It was adopted on March 27, 2014, at the 68th session of the UN General Assembly by an open vote of UN member states, 100 of which voted in favor, 11 against, and 58 countries abstained. 
This meeting of the UN General Assembly was convened specifically to consider the issue of Russia's armed occupation of Ukrainian territory, namely the Crimean Peninsula. There are no provisions in the resolutive part condemning Russia's actions, and there is not even a clear phrase in the text that Crimea is an integral part of Ukraine. However, the Resolution reaffirmed the recognition of Ukraine's territorial integrity "within internationally recognized borders". The UN General Assembly resolution stated that the Crimean referendum would not be recognized. The UN General Assembly called on all states and international organizations not to recognize any changes in the status of the Autonomous Republic of Crimea and the city of Sevastopol based on the aforementioned referendum and to refrain from any actions or behavior that could be interpreted as recognition of any status change (Resolution adopted by the General Assembly on March 27, 2014, 68/262, Territorial integrity of Ukraine). The UN General Assembly's role is crucial in this regard, but this does not give grounds to recognize its status as a legislative body.

Interpretation question of international organizations' constituent, and first of all the UN Charter, has acquired great practical significance. Such acts - charters by their legal nature are treaties. However, they have significant specifics defined in Vienna Conventions. The International Court of Justice also assumes that the general principles and rules of treaty interpretation apply to the UN Charter, as the Charter is a multilateral treaty.

This statement does not deny the right of the organization's bodies to interpret its charters. Applying its provisions, they naturally interpret the charters and act in accordance with interpretation results. Such an interpretation is obligatory only for the organization itself and its inferior bodies. Organization members may or may not agree with this interpretation. However, in practice, these activities also affect the rights and responsibilities of Member States. Due to organization's authority, its understanding of specific rules is taken into account by states.

Organization bodies should carry out a charter interpretation in the part that belongs to their competence and regulates their activities. During the UN Charter development, it was determined that each body would interpret the parts of the Charter that relate to its specific functions. Such an interpretation becomes mandatory if recognized by the states. In this way, constituent acts` content of international organizations is developed.

Officials of international organizations emphasize the importance of dynamic interpretation of constituent acts. A report by the UN Secretary-General to the General Assembly in 1999 stated that the Charter was a "living document." The tendency to improve the Charter's content by interpreting its provisions has been further developed. UN bodies are increasingly interpreting their powers under the Charter, and such an interpretation has legal effect as a result of its tacit recognition by States. The Security Council also broadly interprets its powers. Thus, in accordance with Chapter VII of the UN Charter, the Council has the right to take action in case of acts of aggression, threats to the international world (Chapter VII of the UN Charter), in other words, acts of aggression by some states against others. However, the Council considered it possible to decide on actions to eliminate internal conflicts in many countries, interpreting them as a threat to the world (Danilchenko, 2016 (12): 137-142).

In interpreting their charters, international bodies and organizations also influence the content of other international rules. UN activities are critical in this regard. Foremost the interpretation of UN Charter goals and principles, being an integral part of International law, affects international law itself. One should not forget that any interpretation is carried out in the light of these UN Charter's goals and principles. The most convincing confirmation of this is the Declaration on Principles of International Law concerning Friendly Relations and Cooperation among States in accordance with the Charter of the United Nations, adopted by the UN General 
Assembly in 1970. One should recognize that the acts of interpretation of such subjects, indeed, are of a recommendatory nature.

\section{UN Security Council in the process of interpretation}

The Resolutions of the United Nations Security Council (UNSC) addressed specific issues of interpretation, as since their adoption, following Chapter VII of the UN Charter, they have been binding on all UN member states (according to Articles 25 and 48 of UN Charter). Does this mean that the UNSC, in accordance with some of its functions in support of international peace and security, is authorized to interpret the Charter in a binding manner, and therefore whether its resolutions are binding on member states and other UN bodies? The text and the Charter's concept obviously do not confirm this understanding, as the Security Council is only empowered to take "binding decisions," i.e., measures in individual cases or situations, and not interpretative guidelines of a binding nature. The Security Council's mandate does not cover the authoritative interpretation of treaties other than the UN Charter. However, the interpretation that invariably underlies every decision taken under Chapter VII will always play a unique role in understanding the Charter via those decisions' binding force.

UNSC resolutions, in addition to their interpretive value, are in themselves very important objects of interpretation. Although in legal doctrine, as a rule, it is considered convenient to interpret these resolutions mainly in accordance with VCLT provisions (Gardiner, 2015, 128), international practice in this matter is quite diverse. Thus, the ICJ in its judgement on Kosovo (Kosovo opinion) acknowledged that Articles 31, 32 of the VCLT "may be useful" in this regard, but at the same time pointed out the strong differences between UN Security Council resolutions and treaties, which, according to the Court, mean that the interpretation of these resolutions "requires consideration of other factors". In particular, the Court ruled that "the interpretation of NSC resolutions may require analysis of statements made by UNSC members ' representatives during their adoption, other UNSC rulings on the same issue, as well as further practice of relevant UN bodies and states affected by these resolutions". Based on the fact that the UNSC has defined such declarations as "invalid", it is safe to say that unilateral declarations of independence (and other unilateral acts) conflict with jus cogens if they are related to jus cogens violations (Rubin, 1977: 1-30). Other practical examples of UNSC resolutions, being objects of interpretations, are, of course, the ICTY (International Criminal Tribunal for the former Yugoslavia) and ICTR (International Criminal Tribunal for Rwanda) Charters; both are contained in the annexes to the UNSC resolution and are interpreted by the courts with reference to Art. 31 of the VCLT (Prosecutor v. Zlatko Aleksovski, Para 98).

Daniel Costelloe, Doctor in Law, a lawyer in the Department of Litigation, specializing in International Arbitration (London), and Malgosia Fitzmaurice, a public international law professor (Warsaw), point out another problem. It relates to the development of a unified system of interpretive principles. Such a system does not reflect political, technical, and other contexts, which may unreasonably limit interpretation or even lead to conclusions that run counter to the international body's true intent (Costelloe, Fitzmaurice, 2015 (35): 47-82). For example, UNSC resolutions, being of a sui generis nature, can be politicized. This fact is important because these resolutions cause external legal consequences. D. Costello and M. Fitzmaurice (Costello, Fitzmaurice, 2015 (35): 47-82) propose to develop a particular system of interpretation principles by each contractual body, international organization or to create such system in the practice of courts and tribunals. 
However, interpretive activities of international organizations are diverse and not limited to resolutions. Therefore, it is worth agreeing with T. S. Danilchenko (Danilchenko, 2016: 161-163), who emphasizes that this activity occurs during the discussion in resolving specific issues of law application. The author proposes to consider the interpretive activity as a means of solving a problem of paramount importance for ensuring the international law rules actualization and the whole mechanism of international law`s action in the process of rules implementation.

\section{Conclusions}

Thus, international law's important subjects are international bodies and organizations, whose role in treaty interpretation is steadily growing. International organizations have the right to interpret, but such interpretation is binding only on the organization and its bodies. The UN General Assembly's role is critical in this context, but this does not give grounds for recognizing Assembly's status neither as a legislative body nor as a body with interpretative powers. In this aspect, it should be noted that drawing the line between this kind of interpretation and law-making is a difficult task. In interpreting their charters, international bodies and organizations influence the content of other international rules. However, they do not acquire law-making bodies' status, and their decisions and conclusions are of a recommendatory nature. Law-making acts of international organizations are always created via coordination of political and legal will of sovereign states among themselves. Therefore, it is inadmissible and illegal to apply any forms of pressure and coercion in modern international law sources' creation process. After all, the principle of sovereign equality of states is a fundamental rule of formation of legal positions in creating international legal rules of any level and content.

That is why it is worth noting the growing role of international bodies and organizations as subjects of interpretation, which not only play an essential role in international law-making and international law implementation but also take an active part in their interpretation.

\section{References}

Costelloe, D., Fitzmaurice, M. (2015). Interpretation of Secondary Instruments in International Law. Polish Yearbook of International Law. (35): 47-82.

Danilchenko, T. S. (2016). Rozvytok pravotvorchosti mizhnarodnykh orhanizatsii v umovakh pravovoi hlobalizatsii [Development of law-making of international organizations in the conditions of legal globalization]. Bulletin of Mariupol State University. Series: Right. Mariupol: State University. 12: 137-142. [in Ukrainian]

Danilchenko, T. S. (2017). Mezhi pravotvorchosti mizhnarodnykh orhanizatsii u suchasnykh umovakh: avtoref. dys. ... kand. yuryd. nauk [Boundaries of law-making of international organizations in modern conditions: author's ref. dis. ... Cand. Jurid]. Science: 12.00.11. Kyiv. [in Ukrainian]

Dörr, O., Schmalenbach, K. (eds.). (2018). Vienna Convention on the Law of Treaties: A Commentary. 2nd ed. Berlin: Springer, LVIII.

European Court of Justice (2005). Yassin Abdullah Kadi v Council of the European Union and Commission of the European Communities. Case T-315/01. Judgment of 21 September 2005. II-3649. Para 226.

European Court of Justice. (2008). Kadi and Al Barakaat International Foundation v Council and Commission. C-402/05 P, C-415/05. Judgment of 3 September 2008.

Gardiner, R. (2015). Treaty Interpretation. Oxford: Oxford University Press. 
General Assembly. (2014). Resolution adopted by the General Assembly on 27 March 2014 68/262. Territorial integrity of Ukraine. 1 April 2014. Retrieved from http://www.un.org/en/ga/ search/view_doc.asp?symbol=A/RES/68/262

ICJ, Reports. (2010). Accordance with International Law of the Unilateral Declaration of Independence in Respect of Kosovo. Advisory Opinion of 22 juli 2010, Para 94.

Karvatska, S. B. (2019). Interpretation of international law by international organizations: challenges and perspectives. Legal scientific electronic journal. 1: 187-190.

Reinisch, A. (2001). Developing Human Rights and Humanitarian Law Accountability of the Security Council for the Imposition of Economic Sanctions. American Journal of International Law. 95 (4).

Rubin, A. P. (1977). The International Legal Effects of Unilateral Declarations. American Journal of International Law. Vol. 71 (1): 1-30.

Shpakovych, O. M. (2013). Kryterii klasyfikatsii aktiv mizhnarodnykh orhanizatsii [Criteria for classification of acts of international organizations. Current issues of international relations]. (117): 34-47. [in Ukrainian]

Shpakovych, O. M. (2016). "Miake” pravo mizhnarodnykh orhanizatsii. Vid teorii do praktyky zakhystu prav liudyny. Liber Amicorum do 60-richchia prof. V. V. Mytsyka: monohrafiia [Soft" law of international organizations. From theory to practice of human rights protection. Liber Amicorum to the 60th anniversary of prof. V. V. Mytsyka: monograph / ed.; for order. O. V. Zadorozhny]. Kyiv; Odessa: Phoenix. [in Ukrainian]

Skrynka, D. V. (2019). Rol mizhnarodnykh orhanizatsii u mizhnarodnii pravotvorchosti. Mizhnarodne publichne pravo: pidruchnyk: u 2 t. / V. V. Mytsyk, M. V. Buromenskyi, O. V. Butkevych ta in.; za red. V. V. Mytsyka [The role of international organizations in international lawmaking. International public law: textbook: in 2 volumes / V. V. Mytsyk, M. V. Buromensky, O. V. Butkevych, etc; for order. V. V. Mitsika]. Kharkiv: Law. T. 1. [in Ukrainian]

Smirnova, K. V. (2012). Kontseptsiia "miakoho" prava (soft law) v mizhnarodnomu pravi ta pravi Yevropeiskoho Soiuzu [The concept of "soft" law (soft law) in international law and the law of the European Union]. Ukrainian Journal of International Law. 3: 72 -82. [in Ukrainian] UN, International Law Commission. (2002). Rodriguez Cedeño V. Fifth Report on Unilateral Acts of States. UN Doc A/CN-4/525/Add.2. 10 May 2002, Para 81; 246

United Nation, International Tribunal for theProsecution of Persons. (2000). Prosecutor v. Zlatko Aleksovski. International Tribunal for the Prosecution of Persons, Appeals Chamber. Case No. IT-95-14/1-A. 24 March 2000. Para 98.

United Nations. (1970). Declaration on Principles of International Law concerning Friendly Relations and Co-operation among States in accordance with the Charter of the United Nations. A/RES/25/2625. 24 October 1970. Retrieved from https://www.refworld.org/ docid/3dda1f104.html

Wolfke, K. (1974). Jus cogens in International Law (Regulation and Prospects). Polish Yearbook of International Law. 6: 154-175

World Trade Organization. (2012). United States - Measures Affecting the Production and Sale of Clove Cigarettes. AB-2012-1. WT/DS406/AB/R. 4 April 2012, Paras 252-257. 